\title{
Twentieth Social Science History Association Conference
}

\author{
Guy Baldwin, Perry Chang, and Louise A. Tilly \\ New School for Social Research
}

Labor and class were prominent themes at the 1995 Social Science History Association conference in Chicago (November 16-19). Nine panels sponsored by the SSHA Labor Network showed labor historians engaging an ever-broader set of issues and methodological problems, as did Tamara Hareven's presidential address on how analyses of kinship and class have been transformed by the interdisciplinary history the SSHA has done so much to promote. Labor history was also prominent elsewhere in the program, particularly in sessions on migration, politics, and the welfare state.

A roundtable, "Journeys in Labor History: Perspectives on the Future of the Field," grappled with purported crises in the study of labor. Most of the panelists (Eric Arnesen, Yvette Hugennie, Gunther Peck, Ruth Milkman, James Barrett, and moderator Lawrence Glickman) rejected concerns that the discipline is in peril. Nevertheless, conceptions of three potential crises clearly emerged from the broad and spirited discussion. The first was the current plight of the labor movement itself, along with growing economic inequality and the marginalization of the Left in U.S. politics. Participants disagreed about how much labor historians can or should do to help labor unions in the difficult years ahead.

The second crisis discussed was the declining position of labor history in academia and the crisis of academia in general. Speakers decried the failure of universities to replace retiring labor history giants with bona fide labor historians and criticized the career pressures that junior faculty face today. They reproached themselves for failing to tell the public what academics do-a failure contributing to growing cuts in government research support. The final crisis outlined in the discussion was an epistemological and paradigmatic one. Speakers called for greater integration of race and gender issues into labor history, even while cautioning that this may make it more difficult for labor history to assert a unique character. Speakers also sharply disagreed on the effects poststructuralist scholarship has had on the field.

Another panel featured papers produced by the cross-university research project "Changing Labour Relations and Family Strategies" being conducted in the Netherlands under the sponsorship of the N.W. Posthumus Institute for Economic and Social History. Panelists put varying weight on the two sides of the relationship which is the main theme of the project. Michiel Baud and Theo Engelen, Willem van Schendel, Paul Klep, and Ad Knotter gave brief summaries of their papers, which are available 
as a special issue of Economic and Social History in the Netherlands (1994). Baud and Engelen discussed the positive and negative effects of structural changes such as increased migration, commodification of family relations, and declines in families residing under one roof with attendant changes in internal cohesion. Van Schendel explored how social and economic concepts developed in studies of the West are foreign to scholars working within the development studies framework and act as hindrances to communication. Knotter pointed up problems with the "family economy" concept even in the European cases in which it has been used, and proposed an alternative: the family labor cycle, as developed by Jan Lucassen. Discussant Andrej Plakans suggested that the group investigate the formal network analysis methods and concepts that have been developed by sociologists.

A panel exploring labor systems "on the periphery" in the context of world system theory featured papers by Karen S. Dhanda ("Trinidadian Indentured Servitude"), Bernard Bakama Nume ("Rural Labor Systems in Uganda since 1945"), and Jane Gray ("Towards a World-System Analysis of the 18th Century Linen Industry"). Dhanda discussed labor system transitions in Trinidad in the nineteenth century: from early dependence on full-time casual labor and backward technology on small holdings to the use of indentured labor from India with advancing technology on consolidated larger estates, and then to rapid concentration of remaining plantation and small farming by former indentured servants and others, with differentiation of sugar cultivation and refining by the end of the century. The labor system was flexible, and changed without sharp breaks. Productive and power relationships in the world system do not remain constant, Dhanda concluded, and the core or periphery status of locations shifts gradually over time.

Nume discussed agricultural resettlement policies in Uganda from the 1920 s to the present. Not all important migration patterns have been ruralto-urban: There was a lot of intrarural migration as well. Agrarian labor systems in Uganda have been restructured in response to the departure of young males from the countryside, encouraged by state policies promoting cash cropping which pushed male peasants into migration and wage work to support growing consumption in the cash economy. Smaller-scale agriculture too was pulled into the market, with women carrying the burden of labor in the peasant farm system.

Jane Gray compared the linen industries of eighteenth-century Scotland and Ireland, asking why the Irish were so much more successful in export markets. Calling Immanuel Wallerstein's explanations of this difference incomplete, she turned to the protoindustrialization thesis, arguing that world systems and protoindustrialization theories need each other. The combination makes better sense of contrasts in allocations of family labor in flax cultivation and cloth production, she contended. Gender was also a central factor leading to the different outcomes.

A lively panel on the politics and ideology of working-class consump- 
tion in the United States demonstrated how linking consumption to production has stimulated recent research on class construction. Alan Berolzheimer examined how social scientists produced homogenized models of consumption and "mass culture" in the early twentieth century. Visions of consumer society structured the decisions of retailers and employers, as Meg Jacobs demonstrated in an investigation of department store owner Edward Filene. They also influenced workers in the cooperative movement, as Stephen Milim showed in a paper on cooperative housing in New York City. Discussant Dana Frank praised the panelists' demonstrations of how consumption, as ideology and practice, contributed to workers' selfidentification as members of the middle class during the interwar period. She cautioned, however, that workers' acquisition of property and producers' efforts to stimulate consumption must also be understood as material processes of capital accumulation and class transformation. Discussion forecasted a revised analysis of consumption in American history, one in which the approaches proposed by the panelists would succeed in politicizing the present understanding of consumption as a feature of a generalized "mass culture" developing between the world wars.

More than a dozen conferees attended the Labor Network meeting to plan sessions for the next SSHA conference. The Network chose to feature panels exploring the value of interdisciplinary approaches and crossnational comparisons. Comparative panels on anarchism, race and ethnicity, homework, rural labor, and the experiences of dockworkers were proposed. Panels on work in the borderlands of the United States and Mexico, on migrant labor on the U.S. East Coast, and on transnational constructions of race, ethnicity, and culture were also recommended, and these sessions will anchor the discussion of labor and working-class history at the 1996 conference in New Orleans (October 10-13).

\title{
1996 American Historical Association Meeting
}

\author{
Donna Harsch \\ Carnegie Mellon University \\ Marta V. Vicente \\ Johns Hopkins University \\ Thomas Winter \\ University of Cinncinati
}

The 110th meeting of the American Historical Association, held January 4-7 in Atlanta, featured only a few panels and a scattering of isolated 